\title{
Medium Term Expenditure and Fiscal Management in Nigeria: A Review of the (2005- 2008) Framework
}

\author{
${ }^{*}$ Kanayo Ogujiuba ${ }^{1}$, Benedict Ezema², Omoju Sola ${ }^{1}$ \\ ${ }^{1}$ NationalInstituteforLegislativeStudies, Abuja, Nigeria \\ ${ }^{2}$ Nnamdi Azikiwe University, Akwa, Anambra State, Nigeria \\ *kannyog@gmail.com
}

\begin{abstract}
The Medium Term Expenditure Framework (MTEF) provides the link between policy priorities and the budget. Given that in developing countries in general, and in Nigeria in particular, there is a disconnection between planning, policy and the budget, the MTEF has increasingly been regarded as central to public expenditure reforms. The objectives of this paper are to review the MTEF and budget performance in Nigeria for the period 2005-2008, and identify the challenges undermining the effective operation of the budgetary processes. The paper gathered that the MTEF is the bridge between the national development plan, its underlying policies and the annual budget. Analysis of available data on budget performance during the review period shows that public finance in Nigeria have not been operated within the specifications of the MTEF and the budget, and the priorities expressed in the budget are not always in sync with national objective plans. Some of the identified challenges to effective public expenditure management in Nigeria include lack of citizen's participation in the process, the bureaucratic and inefficient nature of the civil service, large scale corruption, lack of proper coordination between the national development plan and budget, lack of adequate reforms in other key budget areas, such as execution, monitoring and reporting, lack of political commitment, and lack of adequate coordination between the national and sub-national governments.
\end{abstract}

Keywords: Medium Term Expenditure Framework, Public Expenditure Management, Budget, Fiscal Stability, Nigeria

\section{Introduction}

The MTEF provides the "linking framework" that allows expenditures to be "driven by policy priorities and disciplined by budget realities" (World Bank, 1998). Given the disconnection between national development objectives and budget priorities, which is common with developing country, the MTEF has become an integral component of public expenditure management (PEM) reform programs. The relationship between an expenditure framework, fiscal management and macroeconomics can be viewed as closely intertwined or interdependent. Clearly, macroeconomic performance has a significant impact on revenues via its impact on various tax bases, and on expenditure via spending on transfers, sectoral investments, interest payments, foreign exchange rates and inflation. Likewise, fiscal policies and performance have a significant effect on macroeconomic conditions. Fiscal phenomenon such as budget surpluses or deficits, level of public debt, sectoral allocation of government spending, tax rates, level and scope of subsidies and transfers have direct and indirect impacts on macroeconomic performance through their influence on the decisions of various economic actors (i.e. firms, households, etc.). The relationship between macroeconomics and fiscal performance, with a more specific focus on the role of macroeconomic information and analysis in budget management, raises a critical question: what are the goals of public sector budget management? A good budget is one that contributes to the efficient delivery of public goods and services across a range of important sectors (e.g. health, education, transportation, etc.), and does so in a fiscally prudent or sustainable manner, i.e. working within a budget constraint. Recent literature on public expenditure management offers an analytical framework for assessing the level of budget management, premised on MTEF and based on these three characteristics, which are captured using the following terminology:

- Aggregate Fiscal Discipline - keeping spending within a realistic budget constraint such that over time the government is not accumulating substantial debt

- Sectoral Prioritization - allocating resources across sectors in accordance with well-defined and appropriate policy priorities and sectoral strategies

- Technical (or Operational) Efficiency - utilizing resources in a manner that minimizes costs for providing a given set of outputs and outcomes 
In the last few years, there has been a dramatic surge of interest in public expenditure issues by governments, non-governmental agencies and the wider public. Governments are increasingly realising the importance of public expenditure as a viable policy tool for turning the economy towards the path of sustained broad-based growth. Countries with similar natural resource endowments have significantly different development outcome in terms of income distribution and poverty. These differences partly reflect divergences in the ability of governments to direct resources to activities that support the masses. This situation is further compounded by variations in the efficacy of delivering public services, especially basic social services to the poor. The DFID (2001) asserted that public expenditure for development depends not only on spending allocations, but also on appropriate policy and institutional framework for expenditure management and service delivery. The MTEF was introduced in order to overcome weaknesses in resource allocation. Some of these weaknesses include: weak link between development plan, policy and the budget; poor expenditure control; inadequate funding of operations and maintenance; little relationship between formulated and implemented budget; inadequate accounting systems; unreliability in the flow of funds to MDAs and sub-national governments; unreliability of external aid; poor cash management; inadequate reporting of financial performance; and poorly motivated staff. The MTEF aligns government spending with expectations over the medium-term and consequently the annual budget. Government spending is expected to be tailored to policy priorities and national development plan. It is expected to improve Nigeria's fiscal situation through sound expenditure management by promoting fiscal discipline, allocating resources in accordance with priorities and promoting efficient and effective use of public financial resources. It supports ways to maintain a rigid fiscal path, avoid further debt burden, and allocate public resources effectively, and eliminate the divergences between fiscal priorities, economic policies and budgeting. The preparation and implementation of an MTEF consist of interwoven and integrated activities involving bottom-up planning and top-down approval (see Chart below).

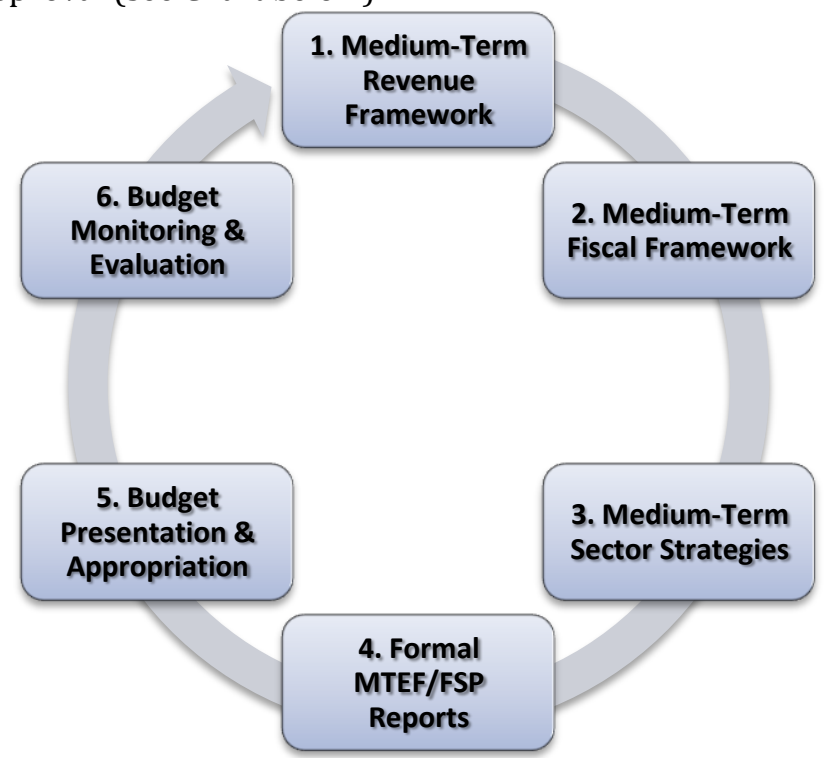

Source: Okogu, 2011

Defining the medium-term expenditures would change the "psychology" of a "needs-based" to an "availability-based" approach as well as enhance the predictability of resource flows over the short- and medium-term. The Nigerian MTEF process is a government-wide strategic policy and expenditure framework within which ministers and line ministries/departments/agencies (MDA) are provided with greater responsibility for allocating resources. The supposed benefits would allow effective management of expenditures and inform decision-makers what would be affordable vis-à-vis priorities. The MTEF consists of a top-down resource envelope taking priorities into account, and a bottom-up estimation by the MDAs of the current and medium-term costs (three year) of programs outlined in Vision 20:2020. Ultimately, expenditures should be matched against available resources. The matching of costs for the current year should normally occur within the context of the annual budget process, which should focus on the need for policy change to reflect macroeconomic conditions as well as changes in strategic priorities of the Government. The process will achieve the following:

- Decisions that are consistent with Government priorities;

- A three-year expenditure plan set within the targets of macroeconomic fiscal strategy; 
- Improve the allocation of expenditures available within the fiscal targets and set out in the fiscal strategy; and

- Provide MDAs with a hard budget constraint as well as increased autonomy, thereby improving incentives for efficient and effective use of funds.

It is on this premise that we seek to review what has been done so far in Nigeria between (2005 - 2008) concerning the MTEF, its efficacy with respect to public finance management, within this new budget process, policy proposition to help strengthen the process and possible lessons to be learnt from the review by other MTEF practising countries. Here, we emphasis the fact that this appears to be one of the few major attempt in reviewing the performance of the MTEF in Nigeria. The objectives of this paper are to review the Medium Term Expenditure Framework and budget performance in Nigeria for the period 2005-2008, and identify the challenges undermining the effective operation of the budgetary processes. Specifically, it examines the goals of the Medium Term Expenditure Framework and as well as the linkage between public expenditure management and macroeconomics. The paper also briefly reviews and draws lessons on the design and impacts of MTEF on public finance and macroeconomic management in some countries.

\section{Operational Stages of the Medium Term Expenditure Framework}

The key element of the MTEF is that it integrates available resources with sectoral programs. Sectoral programs and budgets are determined by the strategic expenditure framework. Once the strategic expenditure framework is developed, the government defines the sectoral resource allocations, which are then used by the sectors to finalize their programs and budgets.

Table 1: The Budget Process and MTEF Nexus.

\begin{tabular}{|c|c|c|c|}
\hline $\begin{array}{l}\text { MTEF/Macro } \\
\text { Framework }\end{array}$ & Budget Process Requirements & Medium Term Strategies & Long Term Goal \\
\hline 1. Fiscal Stability & $\begin{array}{l}\text { - Realistic Medium Term } \\
\text { Economic Outlook and Fiscal } \\
\text { Strategy } \\
\text { - Disciplined } \\
\text { Allocation } \\
\text { - Macro framework used in the } \\
\text { government MTEF must be the } \\
\text { same as that used in MTEF }\end{array}$ & $\begin{array}{l}\text { - Begin to build capacity } \\
\text { as required } \\
\text { - Capacity building in } \\
\text { macroeconomic and fiscal } \\
\text { policy } \\
\text { - Better domestic resource } \\
\text { management }\end{array}$ & $\begin{array}{l}\text { - Capacity to run its own } \\
\text { macro-economic } \\
\text { framework } \\
\text { - Sector analysis to } \\
\text { inform allocation of } \\
\text { resources }\end{array}$ \\
\hline $\begin{array}{l}\text { 2. Comprehensive } \\
\text { Budget Coverage }\end{array}$ & $\begin{array}{l}\text { - All expenditure must be } \\
\text { covered by the budget }\end{array}$ & $\begin{array}{l}\text { - MTEF can be rolled out } \\
\text { across budget over time }\end{array}$ & $\begin{array}{l}\text { All expenditure on } \\
\text { budget }\end{array}$ \\
\hline 3. Predictability & & $\begin{array}{l}\text { - Prioritize most sensitive } \\
\text { spending when there is } \\
\text { budget shortfall }\end{array}$ & $\begin{array}{l}\text { - Budget to serve as a } \\
\text { reliable guide to } \\
\text { expenditure }\end{array}$ \\
\hline $\begin{array}{l}\text { 4. Timely and } \\
\text { accurate data }\end{array}$ & & $\begin{array}{lr}\text { - Enhance } & \text { financial } \\
\text { management } & \text { reporting } \\
\text { systems } & \end{array}$ & $\begin{array}{l}\text { - Prompt capture of all } \\
\text { transactions } \\
\text { - In-year budget } \\
\text { execution reporting }\end{array}$ \\
\hline $\begin{array}{l}\text { 5. Expenditure } \\
\text { Control }\end{array}$ & $\begin{array}{l}\text { - Strong treasury procedures to } \\
\text { accurately control and monitor } \\
\text { revenue and expenditure } \\
\text { - Reduction in cash budgeting, } \\
\text { amendments and virements } \\
\text { - }\end{array}$ & $\begin{array}{l}\text { - Roll out MTEF alongside } \\
\text { Financial } \\
\text { reforms }\end{array}$ & $\begin{array}{l}\text { - Effective } \\
\text { control and audit in } \\
\text { government } \\
\text { - Effective } \\
\text { procurement system } \\
\text { - Strong fublic } \\
\text { management in MDAs is } \\
\text { crucial for forward } \\
\text { budgeting }\end{array}$ \\
\hline
\end{tabular}

The MTEF was first formally introduced in Australia in the mid 1980s to build on the previous forward budget estimates system that was not clearly linked with the annual budgetary process. This newly introduced framework lead to the publication of three year indicative but relatively firm budget 
allocation for all ministries in Australia. Following the foot step of Australia, the framework was adopted by many OECD countries such as Denmark, Netherlands, New Zealand, Norway and others in the 1980s and 1990s.The Breton Wood institutions (the World Bank and IMF) were strong advocates for the use of this approach in developing countries. MTEF developed in Africa and many developing countries of the world in the mid 1990s as a key PFM reform component with the major donor agencies (IMF and World Bank) urging to ensure commitment of resources to Poverty Reduction Strategies (PRSPs). By 2008, more than 100 countries had adopted elements of MTEF (Shand, 2011). The Fiscal Responsibility Act, 2007 provides for the institutionalization of the MTEF in Nigeria. It also mandates the Fiscal Responsibility Commission to enforce and monitor the preparation and implementation of the MTEF. The objectives of the Fiscal Responsibility Act (FRA) are to provide for the prudent management of the nation's financial resources, ensure long-term macroeconomic stability, and secure greater accountability and transparency in fiscal operations within a medium term fiscal policy framework. Section $11-17$ of the Fiscal Responsibility Act provides for the Medium Term Expenditure Framework. According to the Act, the Federal Government after consultation with the States shall prepare and lay before the National Assembly for consideration and approval an MTEF for the next three financial years. Typically, MTFF also contains a set of integrated medium-term macroeconomic projections; and is usually handled by the Federal Ministry of Finance.

- The Medium-Term Fiscal Framework (MTFF): Usually the first step of a successful MTEF process and involves the documentation of the fiscal objectives of the government such as: medium term revenue projections and expenditures of MDAs; government's medium-term macroeconomic targets and projections such as inflation rate targets, interest rate targets, targeted output growth, targeted level of unemployment, exchange rate targets, deficit targets, sustainable debt targets etc.; and finally, the design of top-down resource envelope to be consistent with macroeconomic policy.

- The Medium-Term Budget Framework (MTBF): The MTBF is taken to represent the most basic type of MTEF being implemented. It develops the medium term budget estimates for individual MDAs based on the nation's development priorities and overall fiscal objectives. It identifies and documents key initiatives such as key projects and programs being embarked upon to achieve medium-term targeted macroeconomic goals and objectives. The MTBF costs initiative, prioritizes and phases' them over a medium-term period. The goal is to define the expected outcomes of the projects and programs in clear measurable terms; and finally, link expected outcomes to specific objectives and goals.

- The Medium-Term Sector Strategy (MTSS): Just like the MTEF, the MTSS has as its main objective, to improve the linkage between government spending and the goals of sector plans. The MTSS comprises of activities, methods, processes, projects or programs to be undertaken either alone, or in some combination to achieve specified goals and objectives. It further identifies what must be done to achieve a set of strategic goals and objectives with a very clear, transparent, and published sector goals and targets. MTEF make use of MTSS results, findings and agreed outputs and outcomes.

- The Medium Term Expenditure Framework (MTEF): This is the final stage of the MTEF implementation and entails: adding elements of activity and output based budgeting to the MTBF; better costing of programmes; improving value for money for public spending and reinforcing fiscal discipline and strategic prioritisation.

The Nigerian Experience: Nigeria's first attempt to operationalize the process started in 2004 with the drafting of her first MTFF or the 'Fiscal Strategy Paper' (FSP) as popularly referred to. However, the fiscal paper strategy, documented only the fiscal objectives of the government for that year. Thus, the actual process started in 2005 with the preparations of the FSP for fiscal years 2005-2007. Eight pilot MDAs were used in 2005 while the remaining 19 MDAs were included in 2006 MTEF implementation. The FSP is constantly revised yearly to take into account the prevailing macroeconomic situation of each year as prescribed by the MTEF process. The essence of the revision is to input into the outer years, lessons learnt from the previous years. This is fundamental to the success of the MTBF and the extended MTEF processes. Any misalignment at this stage is likely to impact negatively on the entire planning and budgeting process. It is on this premise that we seek to review what has been done so far in Nigeria between (2005-2008) concerning the MTEF, its efficacy with respect to public finance management, within this new budget process, policy proposition to help strengthen the process and possible lessons to be learnt from the review by other MTEF practising countries. Here, we emphasis the fact that this appears to be one of the few major attempt in reviewing the performance of the MTEF in Nigeria. 
Nonetheless, the Fiscal Strategy Paper (FSP) documents the fiscal objectives of the government against a broader background of key macroeconomic assumptions and targets. Essentially, it sets out the policies of the Federal Government in the medium term relating to taxation, receipts, recurrent non debt expenditure, debt expenditure, capital expenditure, macroeconomic forecasts, borrowing and other liabilities, lending and investment ${ }^{1}$.

Government's medium term revenue projections were based on expected oil production capacities of 2.5 mbpd (million barrels per day) in 2005, $2.59 \mathrm{mbpd}$ in 2006, $2.9 \mathrm{mbpd}$ in 2007 and $2.45 \mathrm{mbpd}$ in 2008. To smoothen out the effect of shortfalls in oil production on the budget, the government adopted an oil rule for preparing the budget. In 2005, the budget was benchmarked at $\$ 30$ per barrel, for 2006 it was $\$ 35$ per barrel, in 2007 it was set at $\$ 40$ per barrel while for 2008 , the benchmark price was set at $\$ 53.58$ per barrel. Similarly, in terms of the government's medium-term macroeconomic targets and projections, VAT collection rates were set at 5\% in 2005 and $10 \%$ for the subsequent years respectively while weighted average duty rates were respectively set at $28 \%$ in 2005 and $17 \%$ for the rest of the years. For company taxes and others taxes, a targeted flat rate of $30 \%$ was taken. On the part of the monetary authorities, the target set for officially exchanging the Naira to the USD during this period were as follows: 133 NGN to 1USD in 2005; 129 NGN to 1USD in 2006; 127.1 NGN to 1USD in 2007 and 126 NGN to 1 USD in 2008, the year 2009 was predicated on 1USD to N125. Inflation rate was set at $11.6 \%$ (2005), 10.9\% (2006) and $10 \%$ for 2007 and 2008 respectively. Similarly, interest targets were pegged at $13 \%$ in $2005,13 \%$ in 2006, and 9\% for 2007 and $10.2 \%$ in 2008 respectively. However, to what extent these targets and assumptions were actually achieved is paramount to the success of the entire MTEF process in Nigeria, and also the extent to which it would impact positively on the economy. For instance, oil production capacities fell short of projected estimates marginally for the review period, exchange rate appreciated more than the set targets, actual interest rate achieved was higher than anticipated and growth rates in real GDP were actually infinitesimal. The details of the projections and the actual realised figures (2005 2008) are reported in Table 2.

Table 2: Key Assumptions and Targets Underpinning FGN Budgeting (2005-2008)

\begin{tabular}{lllll}
\hline Key Assumptions and Targets & $\mathbf{2 0 0 5}$ & $\mathbf{2 0 0 6}$ & $\mathbf{2 0 0 7}$ & $\mathbf{2 0 0 8}$ \\
\hline Oil Production Capacity (in mbpd) & 2.50 & 2.59 & 2.90 & 2.45 \\
Oil Production Quota (in mbpd) & 2.29 & 2.35 & 2.40 & 2.40 \\
Actual Production Capacity (in mbpd) & 2.41 & 2.22 & 2.21 & 2.10 \\
& & & & \\
Projected Oil Price - Market (in USD) & 51.10 & 60.40 & 55.00 & 52.00 \\
Oil Benchmark Price - Budget (in USD) & 30.00 & 35.00 & 40.00 & 53.00 \\
Actual Oil Benchmark Price Used (in USD) & & & & \\
& & & & \\
JV Cash Call (FGN Shares) in USD bns & 4.00 & 4.20 & 4.50 & 4.97 \\
Technical Cost of Oil Companies & & & & \\
Operating Costs (T1) - in USD & 2.14 & 2.12 & 2.94 & 2.74 \\
Capital Expenses (T2) - in USD & 5.37 & 5.82 & 5.48 & 5.58 \\
& & & & \\
Weighted Average Rate of PPT & $83 \%$ & $81 \%$ & $81 \%$ & $81 \%$ \\
Weighted Average Rate of Royalties & $19 \%$ & $18 \%$ & $18 \%$ & $18 \%$ \\
& & & & \\
Average Exchange Rate (NGN/USD) & 133.00 & 129.00 & 127.10 & 126.34 \\
Actual Average Exchange Rate (NGN/USD) & 132.2 & 128.7 & 125.8 & 118.6 \\
VAT Rate & $5 \%$ & $10 \%$ & $10 \%$ & $10 \%$ \\
CIT Rate & $30 \%$ & $30 \%$ & $30 \%$ & $30 \%$ \\
Weighted Average Duty Rate & $28 \%$ & $17 \%$ & $17 \%$ & $17 \%$ \\
Target Inflation Rate & $11.6 \%$ & $10.9 \%$ & $10.0 \%$ & $10.0 \%$ \\
Actual Inflation Rate & $11.6 \%$ & $8.5 \%$ & $6.6 \%$ & $11.6 \%$ \\
Target Interest Rate & $13.0 \%$ & $13.0 \%$ & $9.0 \%$ & $10.2 \%$ \\
Actual Interest Rate & $18.0 \%$ & $17.3 \%$ & $16.9 \%$ & $18.8 \%$ \\
Target Growth Rate in Real GDP & $6.2 \%$ & $6.9 \%$ & $10.0 \%$ & $10.4 \%$ \\
Actual Growth Rate in Real GDP & $6.5 \%$ & $6.0 \%$ & $6.2 \%$ & $6.4 \%$ \\
\hline Sour Varou & & &
\end{tabular}

Source: Various documents of Central Bank of Nigeria, Budget Office and Ministry of Finance

${ }^{1}$ See section 11 (3) (b) of the FRA. 


\section{Literature Review}

The theoretical anchor for the MTEF is a simple approach. The allocation and distribution of resources in a state or an economy can be done through the market mechanism, the government or a combination of the two. Following the advent of Keynesian economics of large scale public sector intervention, the market mechanism lost some appeal. But since the 1970s, market mechanism has been brought to the centre stage in economic management, largely through the promotional activities of the Breton Woods Institutions (the World Bank and IMF). These institutions stress economic liberalization i.e. less government intervention and greater reliance on the private sector as the engine of growth in the economy. The proponents of the free market system argue that under perfectly competitive conditions, the market mechanism is the most efficient way to allocate resources. However, other economists stress that the market may indeed be very powerful in resource allocation, but that it does not have all the answers to economic problems. In the real world, the market can distort resource allocation in some circumstances as a result of market imperfections, market failures, monopoly power, divergence between social costs-benefits and private costs-benefits. In the light of the above limitations of the free market system, the invisible hand of the market must receive assistance from the visible hand of the government through appropriate intervention.

According to the World Bank's Public Expenditure Management Handbook (1998: 46), "The MTEF consists of a top-down resource envelope, a bottom-up estimation of the current and medium-term costs of existing policy and, ultimately, the matching of these costs with available resources in the context of the annual budget process". Furthermore, Le Houerou and Taliercio (2002) posits that MTEF is a potential solution to the de-link between policy making, planning. Empirical studies have attempted to examine the successes and failures of MTEF among African countries and beyond. According to World Bank (2001), MTEF has been adopted by large number of countries across Africa, Asia, Latin America, and Eastern Europe, even though these countries are at different stages in the process of adopting and implementing the framework. Le Houerou and Taliercio (2002) undertook a comparative assessment of MTEFs in nine African countries. According to the assessment, MTEFs cannot have positive impact on Public Expenditure Management (PEM) where other key aspects of budgeting, particularly budget execution and reporting, are weak and where there are low capacity and lack of political will. Oxford Policy Management (OPM) Review (2000) conducted a review of the performance of MTEF in some developing countries which includes Malawi, Rwanda, Nepal, in order to determine if MTEF has been able to achieve positive impact in the area of fiscal discipline and efficient and effective utilisation of resources. The review shows that the impacts of MTEF in these countries are mixed. According to the review, MTEF is not a sufficient solution to poor budgetary outcomes in developing countries; identifying and defining realistic and consistent national and sectoral policies are crucial to the success of the MTEF and budget. Evidences from Nigeria seem not to be different from those of other African countries. Onyekpere (2010) maintains that the MTEF appears not to have captured all revenues and expenditures of government in the medium term. On the revenue side, the recovered investments from the African Finance Corporation lying idle at JP Morgan Chase Bank in New York did not reflect in the revenue projection. On the expenditures side, there is no indication of funding for six new federal universities. And on both sides, the terminal benefits of Power Holding Company of Nigeria (PHCN) workers and expected income from the sale of the companies have not been reflected in the MTEF. The MTEF did not contain information on the quantum of contingent liabilities and measures to be taken to ensure that they do not crystallize or how to deal with them if they crystallize. The MTEF did not describe the nature and fiscal significance of quasi-fiscal activities and what measures to use in containing any liabilities arising from them.

Based on observed obstacles, Makau (2009) tries to articulate some of the constraints of MTEF in Kenya. The first of such constraint is the problem of ownership of the reform. MTEF moves responsibility from the Ministry of Finance to the MDAs as the shift moves from item or input to output. In addition, there is also the issue that most reforms are introduced because of the pressure from the development partners. The issue then arises as to who actually is on the driver seat and sustainability of the changes. Kenya, just like many other countries, chose to use an overlapping set of organizational structures to manage MTEF and these structures have their own weaknesses and strengths. Another problem is the legal framework. Traditionally, the constitution gives the budget the legal backing but MTEF is not normally in the constitution. Countries that do not have a Budget Act like Kenya have struggled to fix interpretation. Moreover, an ideal MTEF is preceded by a comprehensive detailed diagnosis of budget management systems and process. Where Public Expenditure Reviews do not provide this diagnosis, then the MTEF may not make any impact. Makau (2009) conclude that MTEF requires that other reforms complement it 
and thus where there are no reforms in governance, civil service, local government, budget execution, monitoring and evaluation etc then there are limitations to its impact. The process also requires that there is adequate capacity both in Ministries of Finance to guide the process and in Line Ministries for implementation, but we know that these things are lacking especially in developing countries. Finally MTEF does not result in additional resources, and unless there are good criteria for prioritization or extra flow for meeting contingent liabilities, the process may not be effective.

Grigoli, et al (2012) examined the impact of MTEF on fiscal performance using panel analysis. They found that MTEF strongly improve fiscal discipline, allocative efficiency and technical efficiency. In addition, they argued that more advance MTEF phases have larger impacts. On the contrary, Lienert (2007) examines the evidence from PEFA during 2006-2008 and concludes that MTEF in African countries have only a marginal effect on macroeconomic stability and allocative efficiency and no impact on spending efficiency. UNESCO (2010) while examining the approaches, experience and lessons on education MTEF in nine Asian countries found that capacity limitations, public sector leadership, lack of hard budget constraint, inadequate data and poor financial information flows, lack of solid political commitment are some of the major factors undermining the effectiveness of MTEF in these countries.KFW. MB Consulting and OPM (2012) reviews the performance of MTEF in some developing countries and found that the success of MTEF requires a significant level of political leadership, institutional collaboration, organisational capability, particularly within the Ministry of Finance, solid budgetary foundations (budget and forecasting credibility). The study conclude that there is no general approach to implementing MTEF; rather it should be tailored to existing structures and specific circumstances, focus on core processes, and pay attention to change management, coalition building and leadership (Wescott, 2008).

Schiavo-Campo (2008) posited that MTEF has been valuable and effective in promoting growth and development in developed countries mainly because of political/governance and economic/technical reasons. He stated that the strategy was successful particularly in OECD countries mainly because of the quality of governance, accountability, political discipline, active and representative legislature, contestability from vibrant civil society, relatively homogenous population, macroeconomic stability in terms of predictable revenue, technical capacity of ministries, capacity to enforce a hard budget constraint, large pool of highly competent civil servants, availability of reliable data, flexibility of line ministries, etc. According to Schiavo-Campo (2008), some of the major reasons why MTEF has not yielded significant result include lack of technical capacity, poor budgetary institutions, and lack of home-grown and customized practice (MTEF being push unto reluctant countries by donor/funding agencies). He concluded that MTEF is an essential and effective fiscal strategy, but cannot make up for basic weaknesses or lack of political discipline and policy coherence. Besides, it can cause enormous waste, frustration and illusion if introduced prematurely or implemented badly. In a latter work, Schiavo-Campo (2009) stated that the negative impacts of MTEF outweigh its positive impact. He argued that the negative impacts of the introduction of MTEF include little local ownership, distraction from basic budgeting problems, and severe strain on limited capacity. These assertions support earlier finding by IMF (1999) which argued that stringent conditions have to be fulfilled for the benefits of MTEF to materialise. In the same vein, Brumby (2008) argued that the initiation of MTEF in less developed countries have not improved budget preparation and outcomes. He stated that a decade after MTEF, evidence abounds that: budget behaviour has not changed, there is no improvement in macroeconomic balances, there is no link to greater budgetary predictability, and no efficiency gains in public spending.

Oyugi (2008) examined the experiences with medium-term expenditure framework in selected Southern and Eastern African countries. The study found that MTEF had benefited Botswana, Tanzania, Zambia, Kenya and Namibia, in terms of improvement in pro-poor budgetary allocations and increased consultation around the budget. Effective MTEF implementation in these countries has however been undermined by poor forecasts, inadequate capacities, weak enforcement of budget ceilings and low political commitment. These countries are still characterised with under/overspending stemming from inability of line ministries to adhere to their spending limits. ODI (2005) also presented key findings on MTEF in Africa countries. According to the report, initial conditions matter in the effectiveness of the MTEF. In the case of Tanzania, political leadership, macroeconomic and fiscal stabilization, concurrent development of an integrated financial management system, and strong stakeholder involvement were helpful in achieving progress with the MTEF. Despite the glaring difficulties, MTEFs are considered by the World Bank as an indispensable part of a good public expenditure management. 
Fiscal Review and Performance in Nigeria (2005 - 2008): Nigeria's public expenditure management system is characterized with several weaknesses. The inefficiency of the system to improve the lives of many Nigerians reached its zenith in the fiscal year 2004. At this point, the economy was in dire strait. Fiscal deficits were intolerable, poverty abysmal, the rate of unemployment devastating, domestic debt rose to over 1.3 trillion naira as against 0.3 trillion in 1999 (representing over $36 \%$ of the entire), and the nation's foreign exchange policy was mainly dominated by oil prices and foreign debt service obligations. Also, inflation became intolerable to the point that the government had to recourse to large wage increases. During this period, the personnel costs of the government increased from less than 135 billion naira in 1999 to over 368 billion naira at the beginning of the fiscal year 2004. This wage adjustment resulted to significant pressure on domestic prices as inflation went up. The inability of the fiscal authority to effectively manage the nation's fiscal situation compounded the monetary policy targets of low inflation and interest rates. Money supply or broad money (M2) grew from 532 billion naira at the beginning of 1999 to over 1,985 billion naira at the beginning of the fiscal year 2004. This represented an average annual compound growth of $30 \%$. In fact, growth in real Gross Domestic Product (GDP) averaged about 3\% per annum while population growth was put at 2.8\% per annum. This means that growth per capital was virtually stagnant. Against this background, it was evident that the economy was overheated and heading toward a standstill if not salvaged. This led to the drafting of the new 'Fiscal Responsibility Act' to help guide the use and management of the nation's public funds. The 'Act' specifically endorsed the shift away from the traditional 'Line Item' budgeting that had dominated the budget process in Nigeria for many years to the more pragmatic 'Performance and Program' based budgeting couched within a MTEF.

Budget Performance (2005-2008): The budgets for 2005 to 2008 were predicated on oil benchmark prices of $\$ 30, \$ 35, \$ 40$ and $\$ 53.58$ respectively. That is to say, any excess above these set prices were to be saved in the Excess Crude Account (ECA) created for the rainy days. This was a good fiscal practice that had not been adopted in the past and was an indication of steady funds predictability as prescribed by the MTEF process. The overall implications of this were that there would be some level of consistency between government medium term overall fiscal objectives and the MDAs' budget estimates based on national development priorities. Thus, in the actual sense, the credibility of the budget in terms of revenue and expenditure out-turns were out of the question and fiscal deficits above $3 \%$ were intolerable. However, a review of the actual performance of the budget between 2005 and 2008, actually contradicts our priority expectations and that of the MTEF process. Budgeted revenue estimates from all major government sources significantly deviated from actual revenue realized from all major sources for the entire reviewed period. For instance, in 2005 the deviation was over $90 \%$, in 2006 it stood at $91 \%$ while for fiscal year 2007 it was about $87.8 \%$ and for 2008 it was over $98 \%$ respectively. In overall terms, the average percentage deviation between actual revenue and budgeted estimates was about $91.8 \%$. In other words, this implies that actual revenue collected fell below approved estimates by over $92 \%$ during this period. The differences are shown in Figure 1.

Figure 1: Budgeted Vs. Actual FGN Revenue from All major Sources (2005-2008)

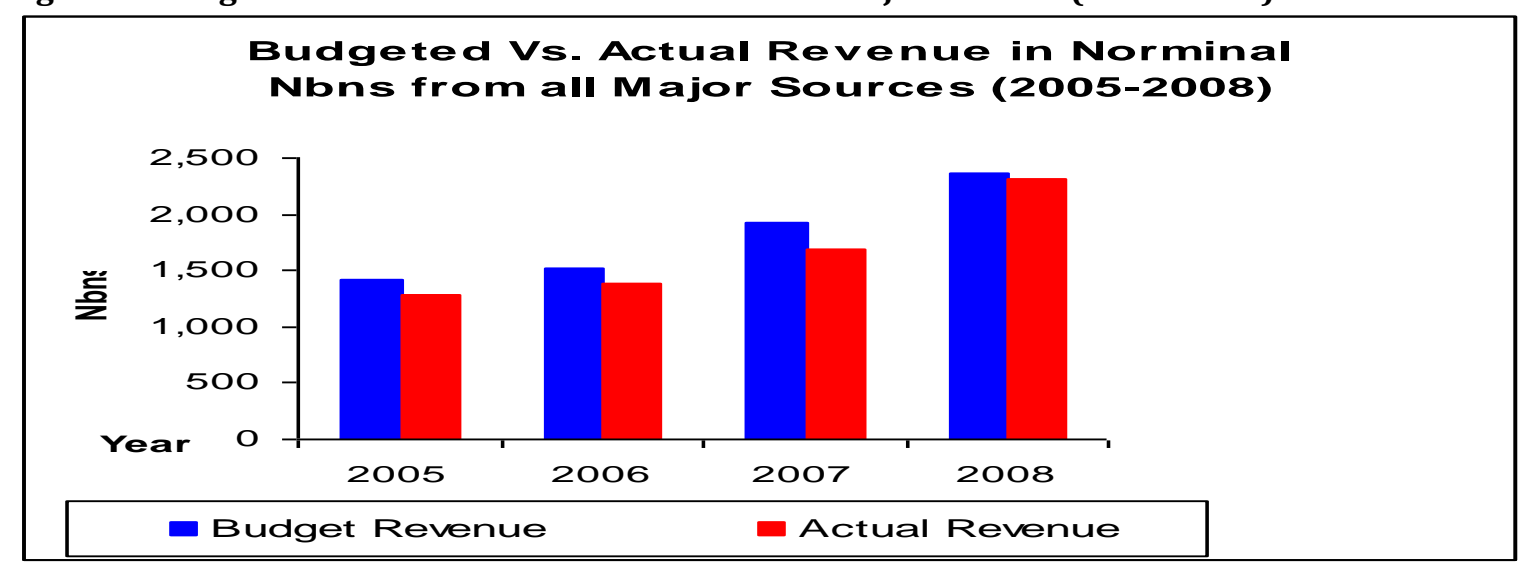

The same can be said about the expenditure out-turns. For instance, while in 2005 the deviation was over $91.5 \%$, that of 2006 stood at $86.6 \%$ and while that for fiscal year 2007 was over $90.4 \%$ that of 2008 was about $89.7 \%$. Again, in overall terms, the average percentage deviation was over $89.6 \%$. This simply indicates that actual expenditure for the entire reviewed period fell short of approved estimates by over $90 \%$. This far exceeds the PEFA benchmark of 3\%. The differences are shown in Figure 2. 


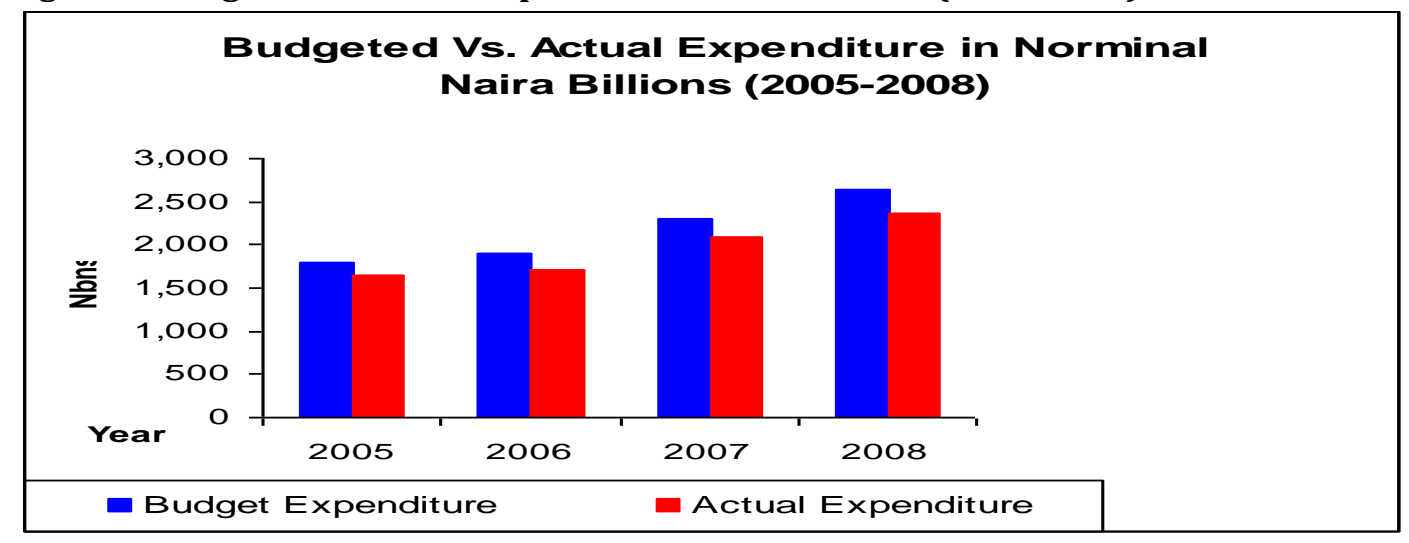

Similarly, matching actual revenue to actual expenditure, the out-turns between revenue and expenditure appear rather too high. For instance, in fiscal year 2005, the percentage deviation of actual revenue to actual approved budget estimates was over $128 \%$. This led to a budget deficit of about 362 billion naira that had to be financed from drawdown from the Excess Crude Account (164 billion naira), borrowing from the same account to the tune of 38 billion naira, proceeds from privatization (15 billion naira) and finally from domestic borrowing of about 144 billion naira respectively. The same can be said about the scenario for fiscal year 2006 where the percentage deviation between actual revenue to actual approved budget estimates was over $122.7 \%$. Again this led to a budget deficit of about 314.5 billion naira that had to be financed also from Excess Crude Account borrowing (240.6 billion naira), sales of government properties (30.9 billion naira), privatization proceeds (19.3 billion naira) and domestic signature bonds (19.8 billion naira) respectively. The deficit trends continued in fiscal years 2007 and 2008 with recorded deficits of about 396.1 billion naira and 62.6 billion naira respectively. However, that of 2008 showed a positive decline from that of 2007 of over 333.5 billion naira as shown in Table 2.

MTEF Performance (2005 - 2008): Has the implementation of the FRA delivered on these promises? First, in terms of fiscal stability, it was lacking during budget preparations. The medium term revenue forecast suggested that what was originally proposed by the government was not what was actually realized during budget implementation. If so, the percentage deviation between budgeted revenue and actual amount realized wouldn't have exceeded 3\% assuming 5\% level of error. The implication of this is that spending agencies had to cost and phase projects and programs based on their indicative envelopes that were not a true reflection of the medium term fiscal frameworks of the government. What spending agencies actually budgeted for was far beyond what was actually realised during these periods. For instance, in fiscal year 2005, the approved estimate was about 1.8 trillion naira while the actual budget was about 1.6 trillion naira. The same trend continued in fiscal years 2006 to 2008 with deviations of over $86.6 \%, 90.4 \%$ and $89.7 \%$ respectively. This meant that planning, budgeting and policy could not be linked together owing to these deviations. Similarly, if we compare the approved revenue estimates ${ }^{2}$ of about 7.2 trillion naira for the entire review period (2005-2008 - excluding borrowing) with the approved expenditure estimates for the spending agencies of about 8.6 trillion naira, it indicates a percentage deviation of about $119.7 \%$, implying that programs and projects of spending agencies were not properly costed and ranked according to their respective scale of preferences (i.e., phasing the least out in terms of ranking for the subsequent years) based on the well articulated ranking matrix grid developed by the MOF/BOF during the preparations of the budgets. If this had been done, despite the short falls in the revenue forecasts, tough agreements would have been reached between the fiscal authorities and the spending agencies concerning their expenditure ceilings to reflect budget realities. The situation is more worrisome when returned capital estimates are reported in the midst of a deficit. How then do we reconcile this situation?

Secondly, concerning budget coverage and comprehensiveness, the review actually indicates that not all expenditures were covered by the budget. For instance in 2005, the budget made provision for a total revenue sum of about 1,286 billion naira while expenditure commitments was set at 1,648 billion naira. This implied a deficit budgeting of over 362 billion naira. The same trends continued in 2006 to 2008 with deficits of over 314 billion naira (2006), 396.1 billion naira (2007) and 66.2 billion naira (2008)

\footnotetext{
${ }^{2}$ This is because budget preparations are done based on approved estimates rather than on actual figures
} 
respectively. Further, a good part of the spending on the Nigeria Integrated Power Projects was taken directly from the Excess Crude Account under the Obasanjo administration without appropriation. Why was this allowed when the fiscal authorities are fully aware that for MTEF to succeed, all expenditure must be covered by the budget? Does it mean that expenditure commitments were arbitrarily fixed and passed by appropriation without being evaluated on the basis of MTEF demands that stipulates that all expenditure must be covered by the budget? It appears this was the case. Thirdly, in terms of funds predictability, the budget performance review also suggests that the MTEF process in Nigeria is seriously handicapped by inaccurate and untimely releases of funds on which MDAS are to execute budget proposals. This alone is immensely damaging to MTEF. For instance, in fiscal year 2008, MDAS budget performance assessment indicates that of a total of 729 billion naira allocated for MDAS expenditure, only about 564 billion was actually released during this period (suggesting a percentage deviation of about $77 \%$ ). Conversely, of this amount actually released, only about N305 billion was actually spent by the MDAS as shown in Table 4. It meant that spending agencies had to include projects and programs that during actual execution could not be covered by the available funds. Nonetheless, the MTEF process allows for the phasing out of unrealistic projects and programs. Was this flexibility exploited or were spending agencies scrambling to keep things afloat, rather than allocating resources on the basis of clear policy choices to achieve strategic objectives. The answer certainly is yes judging from the persistent budget deficits recorded all throughout the periods.

Table 3 shows the budgetary allocations for various ministries, departments and agencies of the Federal Government of Nigeria in 2008. It also shows the actual releases, the variance between the two, the actual spending and the variance between the releases and the actual spending. The budgetary allocation for the year shows that energy accounts for the bulk of the budget, with a total allocation of N126, 416,276,270. This was followed by the agriculture and water resources which had an allocation of N110, 318,221,860. The education, health, environment and housing, transport, women affairs and youths have N52b, N55b, N9b, N56b, N1b and N7b respectively. The amount to be spent by the Presidency, Secretary to the Government of the Federation, Head of Service, National Planning Commission, National Security Advisers are $9 \mathrm{~b}, \mathrm{~N} 3 \mathrm{~b}, \mathrm{~N} 2 \mathrm{~b}, 1.5 \mathrm{~b}, 1 \mathrm{~b}$ respectively. While the agriculture, education and health sectors had a fair share of budget allocation, women affairs, youth, and commerce and industry had a relatively lower share, considering their importance of these ministries to the socio-economic development of the country. In light of the high level of poverty in Nigeria, particularly among women, and the increasing the rate of youth unemployment in Nigeria, the allocations to these sectors are meagre compared to sectors like defence, culture, information, and interior. Similarly, in the light of the present moribund state of industries in Nigeria due to lack of infrastructure, inadequate finances, and the allocation of N4b to the commerce and industry sector is inadequate.

Table 3: 2008 FGN Budget Performance Assessments in Billion Naira (Nominal Terms)

\begin{tabular}{|c|c|c|c|c|c|c|c|}
\hline & $\begin{array}{l}\text { Budgetary } \\
\text { Allocation } \\
\text { (a) }\end{array}$ & $\begin{array}{l}\text { Actual Releases } \\
\text { (b) }\end{array}$ & $\begin{array}{l}\text { Variance } \\
\text { between } \\
\text { and (b) }\end{array}$ & $\begin{array}{l}\% \\
\text { Deviation }\end{array}$ & $\begin{array}{l}\text { Actual Spending } \\
\text { (c) }\end{array}$ & $\begin{array}{l}\text { \% of } \\
\text { Spending } \\
\text { to } \\
\text { Releases }\end{array}$ & $\begin{array}{l}\text { Variance } \\
\text { between } \\
\text { Releases and } \\
\text { Actual Spending } \\
\text { (b) - (c) }\end{array}$ \\
\hline $\begin{array}{l}\text { Agric. \& } \\
\text { Water Res. }\end{array}$ & $110,318,221,860$ & $83,410,426,840$ & $26,907,795,020$ & $76 \%$ & $83,866,212,756$ & 101 & $-455,785,916$ \\
\hline $\begin{array}{l}\text { Auditor } \\
\text { General }\end{array}$ & $1,800,000,000$ & $1,350,000,000$ & $450,000,000$ & $75 \%$ & - & - & $1,350,000,000$ \\
\hline $\begin{array}{l}\text { Com. and } \\
\text { Industry }\end{array}$ & $4,397,445,271$ & $3,298,083,952$ & $1,099,361,319$ & $75 \%$ & $1,579,475,136$ & $48 \%$ & $1,718,608,816$ \\
\hline $\begin{array}{l}\text { Culture and } \\
\text { NOA }\end{array}$ & $6,525,789,992$ & $4,856,842,442$ & $1,668,947,550$ & $74 \%$ & 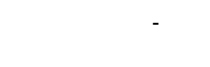 & - & $4,856,842,442$ \\
\hline Defense & $37,464,075,290$ & $28,098,056,468$ & $9,366,018,822$ & $75 \%$ & $17,317,828,498$ & $62 \%$ & $10,780,227,970$ \\
\hline Education & $52,325,688,192$ & $39,259,266,144$ & $13,066,422,048$ & $75 \%$ & $12,729,659,981$ & $32 \%$ & $26,529,606,163$ \\
\hline Energy & $126,416,276,270$ & $112,141,441,993$ & $14,274,834,277$ & 88.7 & $52,090,418,969$ & $46 \%$ & $60,051,023,024$ \\
\hline $\begin{array}{l}\text { Environ. } \\
\text { and } \\
\text { Housing }\end{array}$ & $9,823,673,913.0$ & $7,367,755,434.0$ & $2,455,918,479$ & 75.0 & $6,524,509,885.0$ & $89 \%$ & $843,245,549$ \\
\hline FCTA & $50,858,110,000$ & $38,072,555,000$ & $12,785,555,000$ & $75 \%$ & $29,597,338,429$ & $78 \%$ & $8,475,216,571$ \\
\hline $\begin{array}{l}\text { Federal } \\
\text { Character }\end{array}$ & $570,800,704$ & $428,100,528$ & $142,700,176$ & $75 \%$ & - & - & $428,100,528$ \\
\hline Finance & $5,171,547,351$ & $3,878,660,513$ & $1,292,886,838$ & $75 \%$ & $4,569,711,299$ & $118 \%$ & $-691,050,786$ \\
\hline $\begin{array}{l}\text { Foreign } \\
\text { Affairs }\end{array}$ & $9,148,000,000$ & $6,882,699,395$ & $2,265,300,605$ & $75 \%$ & $14,012,459,317$ & $204 \%$ & $-7,129,759,922$ \\
\hline Health & $55,204,574,952$ & $41,450,431,214$ & $13,754,143,738$ & $75 \%$ & $12,598,883,256$ & $30 \%$ & $28,851,547,958$ \\
\hline
\end{tabular}




\begin{tabular}{|c|c|c|c|c|c|c|c|}
\hline HOS & $1,983,969,600$ & $1,487,977,200$ & $495,992,400$ & $75 \%$ & - & - & $1,487,977,200$ \\
\hline ICPC & $1,488,338,165$ & $1,116,253,623$ & $372,084,542$ & $75 \%$ & $458,066,426$ & & $658,187,197$ \\
\hline $\begin{array}{l}\text { Information } \\
\text { and Culture }\end{array}$ & $5,250,000,000$ & $3,937,500,000$ & 1312500,000 & $75 \%$ & $3,995,550,688$ & $41 \%$ & $-58,050,688$ \\
\hline Interior & $35,114,557,545$ & $25,642,747,951$ & $\begin{array}{l}1,312,500,000 \\
9,471,809,594\end{array}$ & $73 \%$ & $3,848,395,115$ & $\begin{array}{l}101 \% \\
15 \%\end{array}$ & $21,794,352,836$ \\
\hline Justice & $2,346,084,262$ & $1,759,563,196$ & $586,521,066$ & $75 \%$ & - & - & $1,759,563,196$ \\
\hline Labor & $1,922,448,000.0$ & $1,441,836,000.0$ & $480,612,000$ & $75 \%$ & - & - & $1,441,836,000$ \\
\hline Mines and & $3,238,225,825$ & $2,428,669,369$ & $809,556,456$ & $75 \%$ & $805,126,841$ & & $1,623,542,528$ \\
\hline Steel & & & & & & $33 \%$ & \\
\hline National & $1,532,509,346$ & $1,149,382,010$ & $383,127,336$ & $75 \%$ & $115,631,841$ & 10 & $1,033,750,169$ \\
\hline $\begin{array}{l}\text { Planning } \\
\text { NSA }\end{array}$ & $1,000,000,000$ & $750,000,000$ & $250,000,000$ & $75 \%$ & - & $\%$ & $750,000,000$ \\
\hline $\begin{array}{l}\text { Population } \\
\text { Commission }\end{array}$ & $1,181,139,081$ & $885,854,311$ & $295,284,770$ & $75 \%$ & - & - & $885,854,311$ \\
\hline Presidency & $9,037,909,895$ & $6,779,051,421$ & $2,258,858,474$ & $75 \%$ & $3,207,784,177$ & 47 & $3,571,267,244$ \\
\hline $\begin{array}{l}\text { Salaries and } \\
\text { Wages }\end{array}$ & $101,015,369$ & $135,761,527.0$ & $-34,746,158$ & $134 \%$ & - & - & $135,761,527$ \\
\hline $\begin{array}{l}\text { Science and } \\
\text { Tech. }\end{array}$ & $3,059,697,278$ & $9,955,854,297$ & $3,103,842,981$ & 76.2 & $4,044,921,564$ & $41 \%$ & $5,910,932,733$ \\
\hline SGF & $3,339,999,949$ & $2,504,999,961$ & ,289,999,988 & $75 \%$ & $7,178,683,660$ & $\%$ & $2,871,316,301$ \\
\hline $\begin{array}{l}\text { Sports } \\
\text { Commission }\end{array}$ & $4,401,383,294$ & $3,394,748,735$ & $1,006,634,559$ & $77 \%$ & - & - & $3,394,748,735$ \\
\hline Transport & $56,089,596,248$ & $47,160,645,893$ & $8,928,950,355$ & $75 \%$ & $6,586,265,223$ & $40 \%$ & $70,574,380,670$ \\
\hline $\begin{array}{l}\text { Women } \\
\text { Affairs }\end{array}$ & $1,323,194,479$ & $988,969,370$ & $34,225,109$ & $75 \%$ & - & - & $988,969,370$ \\
\hline Youths & $7,242,084,936$ & $5,431,563,703$ & $1,810,521,233$ & $75 \%$ & - & - & $5,431,563,703$ \\
\hline Total & $609,676,357,067$ & $564,990,698,490$ & $64,685,658,577$ & $77 \%$ & $265,126,923,061$ & $54 \%$ & $259,863,775,429$ \\
\hline
\end{tabular}

Source: Various Documents of the Central Bank of Nigeria, Budget Office and Ministry of Finance

For the agriculture and water resources sector, the total budgetary allocation was N110, 318,221,860 but only N83, 410,426,840, indicating a 76\% was released. However, the amount spent was higher than the amount of funds released. In the education sector, a total of N52, 325,688,192 budgeted, but only N39, $259,266,144$ was released. Out of the total releases, only $12 \%$ was actually spent. For the health sector, a total of N55, 204,574,952 was budgeted, out of which only $75 \%$ of the budgeted fund was released for spending. Furthermore, only $30 \%$ of the released funds were actually spent. The Ministry of Finance had a budgetary allocation of N5, 171,547,351, out of which only N3, 878,660,513 was released for spending. However, the ministry spent more than what was actually released to it by a total of N691, 050,786. Similar to the trend in the Ministry of Finance, the Ministry of Foreign Affairs had a budgeted allocation of N9, 148,000,000 but secured a total release of only N6, 882,699,395. However, the ministry ended up spending a total of $\mathrm{N} 14,012,459,317$, which is about $104 \%$ and $47 \%$ higher than the actual releases and budgetary allocations respectively. In summary, for all the MDAs except salaries and wages, funds released are less than the budgetary allocations. The amount spent are also less than the funds released except in the agriculture, finance, foreign affairs, information and culture sector, which spent above the amount that were released to them. This indicates that most MDSs in Nigeria do not operate within the dictates of the budget. While some spent less than their budgetary allocation, others spent far above their budgetary allocations. This is responsible for the wide gap between budgetary allocations and actual spending, leading to the situation of large unspent funds or problems of budget deficit.

Table 4 summarizes the performance of the FGN budget between 2005 and 2008. Specifically, it looks at the revenue, expenditure, fiscal performance, and sources of deficit financing. As expected, oil revenue accounts for the bulk of total revenue during the period, confirming the mono-sectoral nature of the Nigerian economy. Available data also shows that for the period under study, actual revenue generated by the Federal Government fell short of budgeted revenue. In other words, the government consistently failed to meet it revenue target during this period. This was attributed to the poor performance of some or all the sources of revenue. In 2005, total revenue generated by the government was $10 \%$ short of budget estimates. This was due to poor performance of all revenue sources except revenues from customs duties and independent government revenues. The poor performance of oil revenue was more pronounced, as total oil revenue was N979 as against N1161.9 budget estimate. In 2006, revenue generation improved slightly as revenue target achievement increased from $90.3 \%$ in 2005 to $91.1 \%$ in 2006, although oil revenue, customs and independent government revenue failed to meet target. Revenue performance in 2007 recorded a slight slump from the previous year as revenue target achievement fell to $87.8 \%$. This was occasioned by the abysmal performance of oil revenue. Oil revenue experienced a major slump, as total revenue from oil sources was N551.9 billion less than estimated revenue. Other sources of revenue performed beyond expectations. For the period under review, 2008 has the best 
revenue performance, as it achieved 98\% revenue generation target. Oil revenue, though, less than its target, recorded significantly improved performance over the previous years. Of all non-oil revenue sources, only corporate income tax meets its target. However, the improvement in oil revenue and the impressive performance of CIT were unable to cover the shortfall in revenue from other sources, making total actual revenue to fall short of estimated revenue by $2 \%$.

Table 4: Summary Performance of FGN Budget in Nominal Naira Billions (2005-2008)

\begin{tabular}{|c|c|c|c|c|c|c|c|c|c|}
\hline \multirow[t]{2}{*}{ Year } & \multicolumn{2}{|c|}{2005 Budget } & \multicolumn{2}{|c|}{2006 Budget } & \multicolumn{2}{|c|}{2007 Budget } & \multicolumn{2}{|c|}{2008 Budget } & \multirow[b]{2}{*}{ Average } \\
\hline & Est.* & Actual & Est. & Actual & Est. & Actual & Est. & Actual & \\
\hline \multicolumn{10}{|l|}{ Revenue Sources } \\
\hline Oil Revenue & 1161.9 & 979.0 & & $1,134.8$ & & $1,120.10$ & $1,786.10$ & $1,750.80$ & \\
\hline & & & $1,221.0$ & & $1,672.0$ & & & & \\
\hline Value Added Tax & 30.1 & 26.0 & 30.0 & 31.0 & 38.2 & 40.6 & 54.4 & 43.4 & \\
\hline CIT & 81.0 & 76.0 & 107.1 & 107.8 & 89.7 & 152.3 & 109.2 & 194.1 & \\
\hline Custom Duties & 85.7 & 105.0 & 90.0 & 80.2 & 39.5 & 109.2 & 142 & 126.8 & \\
\hline IGR & 65.0 & 100.0 & 75.0 & 33.3 & 86.0 & 268.7 & 268.7 & 198.2 & \\
\hline Total Revenue & $1,423.7$ & $1,286.0$ & $1,523.1$ & $1,387.1$ & $1,925.4$ & $1,691.5$ & $2,360.4$ & $2,313.3$ & $1,322.7$ \\
\hline $\begin{array}{l}\% \\
\text { (Actual/Estimate) }\end{array}$ & & $90.3 \%$ & & $91.1 \%$ & & $87.8 \%$ & & $98.0 \%$ & $91.8 \%$ \\
\hline \multicolumn{10}{|l|}{ Expenditure } \\
\hline Transfers & 90.0 & 79.0 & 91.6 & 91.6 & 102.3 & 102.3 & 162.6 & 187.6 & \\
\hline Debt Service & 356.0 & 394.0 & 290.0 & 254.4 & 326.0 & 232.5 & 372.2 & 372.2 & \\
\hline $\begin{array}{l}\text { Re-cur. Exp. (Non- } \\
\text { Debt) }\end{array}$ & 667.0 & 730.0 & 950.6 & 888.1 & $1,050.0$ & 1,261.8 & 1,327.6 & $1,204.6$ & \\
\hline Capital Exp. & 688.0 & 445.0 & 567.5 & 467.5 & 830.7 & 491.0 & 785.2 & 611.5 & \\
\hline Total Expenditure & $1,801.0$ & $1,648.0$ & $1,899.7$ & $1,701.6$ & $2,309.0$ & $2,087.6$ & $2,647.6$ & $2,375.9$ & $1,527.9$ \\
\hline $\begin{array}{l}\% \quad \text { Deviation } \\
\text { (Actual/Estimate) }\end{array}$ & & $91.5 \%$ & & $86.6 \%$ & & $90.4 \%$ & & $89.7 \%$ & $89.6 \%$ \\
\hline $\begin{array}{l}\text { Revenue/Budget } \\
\text { Out-turns }\end{array}$ & & $128 \%$ & & $122.7 \%$. & & $123.4 \%$ & & $102.7 \%$ & $119.2 \%$ \\
\hline Capt. (\% Budget) & 48.3 & 34.6 & 37.3 & 33.7 & 43.1 & 29.0 & 33.3 & 26.4 & $30.9 \%$ \\
\hline Deficit & -377.3 & -362.0 & -376.6 & -314.5 & -383.6 & -396.1 & -287.2 & -62.6 & -283.8 \\
\hline Def. (\% Budget) & -26.5 & -28.1 & -24.7 & -22.6 & -19.9 & -23.4 & -12.2 & -2.7 & $-19.2 \%$ \\
\hline GDP & & $14,572.20$ & & $18,546.60$ & & $22,848.90$ & & $24,848.90$ & \\
\hline Deficit/GDP (\%) & & -2.5 & & -1.7 & & -1.7 & & -0.3 & $-1.5 \%$ \\
\hline $\begin{array}{l}\text { Sources of } \\
\text { Financing }\end{array}$ & & & & & & & & & \\
\hline Excess Crude & 164 & 164 & 240.6 & 240.6 & & & & & \\
\hline $\begin{array}{l}\text { Borrowing from } \\
\text { Excess Crude }\end{array}$ & & 38 & & & & & & & \\
\hline $\begin{array}{l}\text { Sales of FGN } \\
\text { Properties }\end{array}$ & 15 & & 30.9 & 30.9 & 125 & 125 & 50 & 50 & \\
\hline $\begin{array}{l}\text { Privatization } \\
\text { Proceeds }\end{array}$ & 94 & 15 & 19.3 & 19.3 & 40 & 40 & 50 & 50 & \\
\hline Domestic & & 144 & & & 200 & 200 & 155.5 & 155.5 & \\
\hline Bond/(Borrowing) & & & & & & & & & \\
\hline Signature Bonds & & & 19.8 & 19.8 & & 40 & 32.7 & 32.7 & \\
\hline Opening Balance & & & & & & & 217.7 & 217.7 & \\
\hline Others & & & & & & & 32.1 & 32.1 & \\
\hline $\begin{array}{l}\text { Total Sources of } \\
\text { Financing }\end{array}$ & 273 & 361 & 310.6 & 310.6 & 365 & 365 & 538 & 538 & 393.65 \\
\hline $\begin{array}{l}\text { Financing Surplus } \\
\text { Gap }\end{array}$ & -104.3 & -1.0 & -3.9 & -3.9 & -18.6 & -31.1 & 408 & 475.4 & 109.85 \\
\hline
\end{tabular}

Source: Various documents of Central Bank of Nigeria, Budget Office and Ministry of Finance

On the expenditure side, actual expenditure is less than estimated expenditure for the period under review. Capital expenditure accounts for less than $40 \%$ of total expenditure in all the years. This shows the skewed nature of public expenditure towards recurrent expenditure. The implication of this is that the necessary investments and infrastructure needed for economic growth, development and poverty alleviation may not be adequately provided. This will slow economic development drive of the government and may deter the attainment of the various development objectives as stated in the Millennium Development Goals (MDGs) and Vision 20: 2020. Furthermore, total expenditure fell short of estimated or planned expenditure for the period under review. In 2005, actual expenditure was $91.5 \%$ of total estimated expenditure captured in the budget. Similarly, in 2006, 2007 and 2008, total expenditures were also less than estimated expenditure by $3.4,9.6$ and $10.3 \%$ respectively. The poor performance of 
expenditure during this period was more pronounced in capital expenditure, as capital expenditure fell substantially from budgeted estimates. Though recurrent expenditure also reduced from budgeted estimates in 2006 and 2008, the variance was not as wide as that of capital expenditure. The revenuebudget out-turns shows that actual expenditure exceeds revenue by 28, 22.7, 23.4 and $2.7 \%$ in 2005, 2006, 2007 and 2008 respectively. The fiscal performance of the government shows that deficit averaged $\mathrm{N} 283.8 \mathrm{~b}$ during the period under review. Specifically, deficit decreased from N362b in 2005 to N314b in 2006. It, however, increased to N396.1b in 2007 before plunging to N62.6b in 2008. Deficit as percentage of the total budget also reduced significantly during the period. In 2005, deficit as percentage of total budget was $28.1 \%$, but it reduced to $22.6 \%$ in 2006 , before witnessing a massive reduction to $2.7 \%$ in 2008. Deficit as percentage of GDP also witnessed significant reduction from $2.5 \%$ in 2005 to $1.7 \%$ in 2006 and 2007 to $0.3 \%$ in 2008 . This is in conformity with the objective of reducing budget deficit, as enshrined in the MTEF. The use of sales of FGN properties, privatisation proceeds, and excess crude as source of deficit financing is not in conformity with international practices. Deficit is expected to accrue after every sources of government revenue has been exhausted and revenue source still lags behind expenditure. Excess crude, sales of FGN assets and privatisation proceeds should be part of government non-oil revenue and not a source of deficit financing.

\section{Policy Issues}

Nigeria's budgetary process faces a lot of challenges partly because the country was under military dictatorships for 29 out of its 52 years of nationhood. As such, budget preparation and execution to a very large extent exclude citizens' participation. Civil society lacks the skills that will enable them participate in the budgetary process. The current structure of budget systems and processes in Nigeria do not admit for the participation of non-state actors. More disturbing is the fact that the National and State Assemblies lack adequate capacity and enabling environment to play oversight functions on the budget process. Another area of challenge is the civil service structure which should provide the backbone for the budget process. The structure does not support participatory, transparent and people-oriented budget. The nonchalant attitude of public servants makes participation in the budget formulation very low. It is seen as just one of those civil service annual routines. Auditing and evaluation of the budget implementation is hampered by the absence of enabling laws which provide access to information regarding the utilization of public funds. Nigeria's judicial system remains largely untested in citizens' enforcement of the budget provisions. Constitutional gaps, reflected in ouster clauses, still forbid citizens from bringing certain forms of actions. Few organizations exist in Nigeria today that can do effective budget work particularly with respect to advocacy and analysis. Apart from inadequate legal framework, large scale corruption culminating in lack of transparency and accountability also hamper the budgetary process. There is the near absence of donor coordination and the unpatriotic attitude of some of Nigeria's Civil Society Organizations towards the budgetary process does not help matters.

There are potential risks that are inherent in moving from the realm of the conceptual to the operational (Le Houerou and Taliercio, 2002). The first is trying to implement the concept of the MTEF independently without taking cognisance of the current specific conditions and structure of the economy. Another risk is in thinking of the MTEF as a separate package of reforms in isolation from other basic budgetary reforms. Budget execution and reporting would have to be critically addressed and strong attention has to be paid to the political and institutional factors. Nonetheless, one of the major setbacks of the budgetary tool (MTEF) in Nigeria is improper revenue forecasting. This is mainly because, a major source of revenue earning is oil and gas constituting over $90 \%$ of total revenue. However, oil is an exhaustible resource with an unstable price due to its susceptibility to unanticipated shocks. Any sudden drop in the price of oil automatically affects the level of revenue accruing to the federation accounts and hence, proper expenditure planning. If however, the real sector had been a major growth driver, it would have counteracted the negative effect of oil price fall on the budget. It is therefore important for the government to diversify the production base of the economy. Moreso, the credibility of the MTEF will depend on the implementation of budget. Poor budget implementation has been hampered by delay in the release of funds and the approach to disbursement. KFB, MB Consulting and OPM (2012) summarise the challenges and obstacles to the success of MTEF in Nigeria. According to the study, weak quality of cost data, weak budget monitoring and evaluation, traditional budgeting system, separate presentation of capital and recurrent expenditure, regular tension between the executive and the legislature, and nonadherence to budget preparation calendar. 
Outstanding Issues and Next Steps: The lack of linkage between the MTEF and the national planning objectives and its objectives is the major obstacle to the effectiveness of the budget in Nigeria. National planning gives direction to the government on its priorities and objectives in the short, medium or long term. While the national planning could stand as the long term framework, the MTEF is the medium/short term plan and the budget is the annual plan. Thus, there must be harmony between the objectives and priorities of the national plan, MTEF and the budget. Presently, the national planning framework in Nigeria is the Transformation Agenda and the Nigeria Vision 20: 2020. The MTEF should be designed as an integral part of the national planning framework. This should be done by ensuring that the objectives and priorities of the MTEF should be in sync with the national objectives. Similarly, the annual budget should derive its objectives and priorities from the long-term national plan already established by the government. The high level of corruption has made public expenditure ineffective in promoting economic growth and reducing the level of poverty in Nigeria. Over the years, public expenditure has increased astronomically while poverty levels and other development indicators have also worsened. Nigeria's expenditure index of capture currently stands at 0.4 , indicating that only $40 \%$ of total expenditure gets to the people. Misappropriation of funds meant for development projects is a common practice, thereby eluding the people of the benefits of infrastructural developments. Regulations and institutions meant to ensure effective monitoring of public expenditure are weak. It is important that government creatively improve the index of capture to facilitate economic growth and development. This will have a far reaching effect on ensuring that the people benefit more from public expenditure.

Presently, weak index of capture in expenditure in Nigeria coupled with weak institutional framework for expenditure management and service delivery is the most significant cause of the weak linkage existing between government economic wide-policy, planning and budgeting. Most often, policy making, planning and budgeting take place independently of each other. Planning is often confined to investment activities, which in many developing countries refers to a series of donor-funded projects. Capital expenditures are already largely accounted for through the planning process, and a large portion of recurrent expenditures are pre-committed to the wage bill. For this reason, annual budgeting is reduced to allocating resources thinly across domestically funded "investment" projects and to the non-wage portion of the recurrent budget. In addition, MDAs spend on an ad hoc basis because even small discretionary allocations are rarely predictable. A fundamental principle of good governance requires that public office holders should be accountable for their performance. Yet, institutional mechanisms to ensure transparency and accountability are weak. There is a need for a regular public expenditure and financial accountability performance assessment of all spending agencies in the federation. This is costly but surely it would improve overall budget performance in terms of credibility, comprehensiveness and transparency, policybased budgeting, funds predictability and control in budget execution, accounting, recording and reporting, and finally in terms of external scrutiny and auditing. This is usually the first major step in reforming and continued reform of the PEM system. A repeated application to all the spending agencies is required if the MTEF process is to succeed.

Also, it is very important for the fiscal authorities to improve macroeconomic management and revenue collection so that revenue shortfalls do not necessitate adjustments to the budget estimates Building of capacity in key government sectors directly involved with the MTEF framework. The Budget Office of the Federation needs capacity building in budget/policy costing, monitoring and evaluation of programme/policy while for spending agencies, capacity is needed in priority setting exercise. Furthermore, political commitment and endorsement at the highest level is needed to make and abide by the difficult decisions likely to be involved in the restructuring of expenditures. Some MDAs need to scale back their activities so that more resources can be directed to higher priority sectors. There is need for improvements in expenditure control so that decisions are not always undermined by over expenditures and reallocation of funds during budget implementation. The whole system needs to be improved in terms of expenditure and results reporting. In addition, there is need for constant briefing, dialogue and interaction between elected officials in the legislature; executive and senior management during the entire fiscal year. This requires regular mid-term reports made available to the general public, which would be useful for budget monitoring and expenditure tracking. Drawing lessons and achievements from other countries practicing MTEF could assist the process in Nigeria.

There is need to ensure that MDAs operate within the confines of the MTEF and the budget. The review of the 2005-2008 budget performance shows that MDAs often operate outside the specifications of the MTEF. It was found that most MDAs either overspend or spend less than their budgeted estimates. This has added to the current challenge of over-bloated deficit in Nigeria. Efforts should be made to ensure 
that leaders of MDAs are personally held responsible and accountable for funds allocated to their offices. This could be done through efficient monitoring and evaluation of projects and programmes included in the budget by the appropriate authorities. In particular, the appropriate committees of the National Assembly should improve their oversight functions of the various MDAs. This is to ensure strict compliance with the details of the budget and check excesses. Besides, the performance of the various MDAs, in terms of its ability to execute its programmes effectively and efficiently, should be used as a parameter for judging the amount allocated to MDAs in the subsequent year. The role of sub-national levels of government in ensuring macroeconomic stability and stimulating growth and development cannot be over-emphasized. The efforts of the Federal Government at ensuring development may not be successful if not adequately complemented by those of the sub-national governments. However, accountability at the lower levels of government in Nigeria has been neglected and inadequate. For example, the Fiscal Responsibility Act of 2007 covers only the Federal Government, as the State Governments are not legally bound by it. There is need to enhance the capacity of sub-national governments to efficiently manage resources and provide social services to the citizens. Adopting the Fiscal Responsibility Act by state governments, developing modality for assessing fiscal prudence at the lower levels of governments are steps in the right direction to enhance the quality of financial management, transparency and accountability of government institutions.

\section{Conclusion}

This paper examines the Medium Term Expenditure and Fiscal Management in Nigeria for the period 2005-2008. The paper specifically, examines the objectives of MTEF, and the performance of the 20052008 budgets in relation to the objectives of MTEF. Finally, the paper discussed the challenges and factors that have undermined the effectiveness of MTEF in Nigeria. The objectives of MTEF are to ensure fiscal discipline, promote inter- and intra-sectoral resource allocation, enhance budget predictability and credibility, aid efficient use of public resources, and facilitate political accountability. From the available data, there is little evidence to show that MTEF has had significant impact on budget outcome in Nigeria. Specifically, recurrent expenditure still account for a large chunk of public expenditure, as against capital expenditure, which is assumed to have more impacts on the standard of living of the populace. Similarly, the sectoral allocation of public expenditure is also not in sync with the government development objectives of poverty eradication and extensive balanced development. Government spending on propoor sectors such as health, education, housing, agriculture, etc are not commensurate with the national objective of poverty alleviation. Allocations to The Presidency, Office of the Secretary to the Federation, Defence, etc far outweigh allocations to the pro-poor sectors and this partly explains why poverty has not reduced despite substantial increase in public expenditure. In addition, shortage of skilled personnel, lack of technical and institutional capabilities, high corruption level, bureaucratic nature of the civil service, and frequent disagreements between the executive and legislature which often leads to delay in budget passage. From this study, it is clear that MTEF alone is not sufficient to enhance the efficiency of public financial management in Nigeria; it needs to be implemented alongside other complementary reforms. It is evident that MTEF requires other complementary reforms to be effective in developing countries, Nigeria inclusive. From the review of the literature, it was clear that public sector leadership, lack and poor implementation of budget constraints, inadequate data and poor financial information management, lack of political commitment, import of "foreign-made" MTEF, poor forecasting ability, etcare some of the general issues undermining the effectiveness of budget reforms in developing countries, including Nigeria. Therefore pragmatic reforms are required in these areas to enhance the effectiveness of MTEF in Nigeria.

\section{References}

Brumby, J. (2008). MTEF's: Does the Walk Match the Talk? Paper Presented at the World Bank's From Diagnosis to Action Workshop, March 21.

DfID (2001). Understanding and Reforming Public Expenditure Management: Guidelines for DFID, Version 1, London: Department for International Development, March.

Grigoli, F., Mills, Z., Verhoeven, M. \& Vlaicu, R. (2012). MTEFs and Fiscal Performance: Panel Data Evidence, Policy Research Working Paper No. 6186, 1-42, September.

IMF. (1999). Manual on Fiscal Transparency (http://imf.org/fiscal/manual).

IMF. (2000). Medium Term Expenditure Framework Debate, PREM Week, held on November 21, at the University of Maryland Conference Center. 
KFW, MB Consulting \& OPM. (2012). Medium Term Expenditure Frameworks: International and Regional Experience, Reflection and Discussion Paper for the Budget Analysis Group.

Le Houerou, P. \& Taliercio, R. (2002). Medium Term Expenditure Framework: From Concept to Practice: Preliminary Lessons from Africa, World Bank African Regional Working Paper Series No. 28, Washington, DC: World Bank.

Lienert, I. (2007). Inherited Budget Practices and Medium-Term Expenditure Frameworks in Francophone and Anglophone Africa, In Are We Asking the Right Questions? Embedding Medium Term Perspective in Budgeting, $4^{\text {th }}$ Annual CABRI Seminar, 13-15 December, Accra, Ghana.

Makau, N. P. (2009). Using MTEF as a Tool for Improved Fiscal Management, Ministry of Finance, Kenya.

ODI (2005). Linking Policies and Budgets: Implementing Medium Term Expenditure Frameworks in a PRSP Contest, ODI Briefing Paper, June.

Okogu, B. (2011). The Budgeting Process: Roles, Responsibilities and Challenges, Presentation to Members of the National Assembly, Abuja, on 8th June, 2011.

Onyekpere, E. (2010). Analysis of 2011-2013 Medium Term Expenditure Framework, Business News.

Oxford Policy Management Review. (2000). Medium Term Expenditure Frameworks: Panacea or Dangerous Distortions? OPM Briefing Notes Paper 2, Oxford: Oxford Policy Management, May.

Oyugi, L. N. (2008). Experiences with Medium-Term Expenditure Framework in Selected Southern and Eastern African Countries, A Comparative Study for the Southern and Eastern Africa Policy Research Network (SEAPREN), SEAPREN Working Paper No. 7, August.

Schiavo-Campo, S. (2008). Medium-Term Expenditure Frameworks in Developing Countries: Genesis, Myths, Realities, and a Way Forward, Paper presented at the IMF Fiscal Affairs Department Seminar, October 2.

Schiavo-Campo, S. (2009). Potemkin Villages: The Medium Term Expenditure Framework in Developing Countries. Public Budgeting and Finance, 29(1), 1-26.

Shand, D. (2011). International Experience and Best Practice in Implementing Medium Term Expenditure Frameworks, Paper presented at IMF Workshop, Almaty, Kazakhstan, 26 - 27 May, 2011.

Wescott, C. (2008). World Bank Support for Public Financial Management: Conceptual Roots and Evidence of Impact, Background Paper to Public Sector Reform: What Works and Why? IEG Working Paper.

World Bank (1997). Public Expenditure Review, (Vol. 1 \& 2), Washington, DC: World Bank.

World Bank (1998). Public Expenditure Management Handbook, Washington, DC: World Bank.

World Bank (2001). Public Expenditure Management and Accountability: Evolution and Current Status of World Bank Work, Poverty Reduction and Economic Management Network, Operation Policy and Country Services Network, April. 